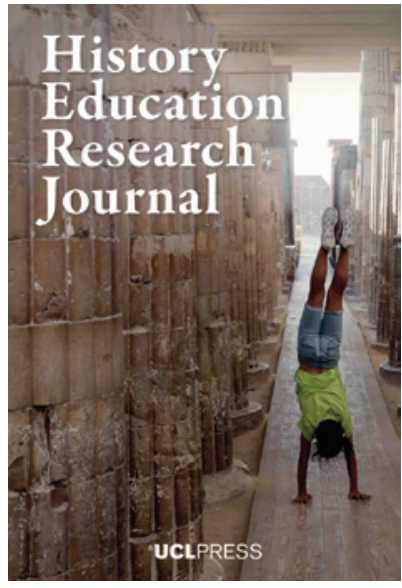

${ }^{\Perp}$ UCLPRESS

HISTORY EDUCATION RESEARCH JOURNAL

ISSN 2631-9713 (Online)

Journal homepage:

https://www.uclpress.co.uk/pages/history-educationresearch-journal

\title{
Identifying aspects of temporal orientation in students' moral reflections
}

Niklas Ammert (D), Heather Sharp (D), Jan Löfström (iD and Silvia Edling (D)

\section{How to cite this article}

Ammert, N., Sharp, H., Löfström, J. and Edling, S. (2020) 'Identifying aspects of temporal orientation in students' moral reflections'. History Education Research Journal, 17 (2), 132-50. Online. https://doi.org/10.14324/HERJ.17.2.01

Submission date: 8 June 2019

Acceptance date: 10 May 2020

Publication date: 20 October 2020

\section{Peer review}

This article has been peer reviewed through the journal's standard double-blind peer review, where both the reviewers and authors are anonymized during review.

\section{Copyright}

(C) 2020 Ammert, Sharp, Löfström and Edling. This is an open-access article distributed under the terms of the Creative Commons Attribution Licence (CC BY) 4.0 https://creativecommons.org/ licenses/by/4.0/, which permits unrestricted use, distribution and reproduction in any medium, provided the original author and source are credited.

\section{Open access}

The History Education Research Journal is a peer-reviewed open-access journal. 


\title{
Identifying aspects of temporal orientation in students' moral reflections
}

\author{
Niklas Ammert* - Linnaeus University, Sweden \\ Heather Sharp - University of Newcastle, Australia \\ Jan Löfström - University of Turku, Finland \\ Silvia Edling - University of Gävle, Sweden
}

\begin{abstract}
History education comprises moral issues and moral aspects, often perceived as an important and meaning-making foundation that makes learning relevant and interesting. The interrelationship between time layers fuels historical interpretations and facilitates perceptions of moral issues. This article focuses on a study investigating how secondary school students express inter-temporal relationships in encounters with a morally challenging historical event, which for the participants would have been a moral dilemma. Using historical consciousness as the theoretical framework, a matrix linking two prominent theoretical models - Jörn Rüsen's (2004) types of narratives and Ann Chinnery's (2013) strands of historical consciousness - was developed to analyse and categorize secondary school students' expressions of temporal orientation. To carry out the research, 15-year-old Finnish and Swedish students read an excerpt from Christopher Browning's (2017) book Ordinary Men: Reserve Police Battalion 101 and the Final Solution in Poland (originally published in 1992). The students answered and discussed open-ended questions regarding the relevance of the text to their lives and others' lives, and the applicability of this historical situation to Europe now and in the future. Using this empirical material, the analysis provides a tentative overarching depiction of students' expressions of temporal orientation, and reports on findings of how temporal orientations relate to moral reflection.
\end{abstract}

Keywords: temporal orientation; moral reflection; secondary school students; Finland; Sweden

\section{Introduction}

History teaching and history education more broadly have an important role in facilitating learning opportunities and staging situations where students encounter history. The situations can be complex and multifaceted, not least because students encounter history, historical narratives, representations of history and uses of history in a multiplicity of ways. Encounters with history also take place outside the formal school classroom, in everyday life such as: through family connections; through visits to public history sites such as museums; incidental encounters such as with public monuments and memorials; through popular culture; and as consumers of the news and other media. History is understood as both personal and as a part of the public sphere, and, as such, encounters with history do not take place in an empty space, devoid of context, but are often based on and framed by the experiences, knowledge and interests of the individual. 
These encounters with history often entail inter-temporal relationships between interpretations of the past, understandings of the present and perspectives on the future, as theoretically framed by, and defined as, a historical consciousness. Questions asked of, and interpretations made of, the past are anchored in the needs and the context of the present (Karlsson, 2016: 117). The concept of historical consciousness has been a strong focus of history didaktik in continental and northern Europe since the 1980s. However, the concept is contested, and it is regarded by some as being too vague or metaphysical (see Straub, 2006: 50-1) for empirical research to be conducted or for its application in the classroom to be viable. One major objection has been that it is not obvious how historical consciousness can be definitively identified, analysed or categorized. The questioning of its veracity underlines the need for further theoretical work and methodological refinement to be undertaken to develop a deeper understanding of the applicability of this concept to educational contexts.

Since the influential Youth and History project (Angvik and Von Borries, 1997a, 1997b) was released in the late 1990s, a multitude of studies on historical consciousness have been undertaken (see, for example, Wilschut, 2012; Rosenzweig and Thelen, 1998). An overview of the current state of the field is presented in the recently published anthology Contemplating Historical Consciousness (Clark and Peck, 2019). The concept refers to how people relate with time, and their ability to construct meaningful relations between the past, the present and the future (temporal orientation, as explained above). In the history education context, how historical consciousness can be identified and analysed has been researched by Andersson Hult (2016) and Alvén (2017), exploring how individuals interpret and discuss the past and its relatedness to the present and the future when they encounter representations of history.

Historians routinely work with ethical, moral or value-laden topics. As Mommsen (2000: 48) asserts: 'The historian deals constantly with values, ideological positions and different normative systems - these are the very fabric of what he studies, and their mutual confrontation constitute in a way, the dynamism of the historical process' (see also Cotkin, 2008: 298). Moral aspects are central for meaning making (Foster and Yeager, 1998: 1-7; Colby, 2008: 60-2; Löfström, 2014: 517-18). However, moral values do not stop at the basic level of only illuminating or stating something; they are foundational to our relationship to history (Edling and Sharp, 2018).

Issues connected to ethical and moral values can thus be assumed to deepen knowledge and stimulate students' historical consciousness. Milligan et al. (2018: 470) argue that 'for example, when students assess historical actions, when they seek to understand others' perspectives, or when they consider how best to move forward from the past, they move into the practice of ethics'. The German historian Jörn Rüsen (2004: 67-8) stresses this reciprocity, and asserts that historical consciousness makes an essential contribution to moral-ethical consciousness by providing a wider context for the moral issues, writing: 'history clothes values in temporal experience. Historical consciousness transforms moral values into temporal wholes.' In other words, Rüsen (ibid.) is saying, traditions, rules of conduct, concepts and experiences are mediated and made comprehensible in encounters between temporal dimensions. Factual knowledge about the past also strengthens moral interpretations. At the same time, moral values are important for stimulating a historical consciousness by bridging the distance in time and by facilitating understandings of the past (Ammert, 2010: 25-6). Historical moral dilemmas, or situations when moral values or acceptable conduct have been violated, increase interest in the past and provide opportunities for interconnection between time layers. Turning points in life and in history seem to act as motivators for people to turn to the past to orient themselves and to interpret what is 
happening in the here and now, and what it might mean for the future. Major changes such as wars and terror attacks - but also changes to personal circumstances - can affect thinking in and over time. The theoretical interrelationships between historical consciousness and moral consciousness are complex and interwoven. However, there are two discernible interpretations of the relationships. Rüsen (2004: 78) has argued that historical consciousness could be conceptualized as a 'synthesis of moral and temporal consciousness'. This interpretation means that moral consciousness is a component of historical consciousness. A partly different view is presented by Carlos Kölbl (2009: 89), who has shown how a 'touchable past' - a closeness to the past evoked by 'plastic, strong and moving images of the past' - facilitates historical understanding. Our hypothesis, or starting point, is that historical consciousness and moral consciousness are mutually dependent and mutually support each other's development. Our conclusion is that moral values and moral issues are crucial for developing a historical consciousness (Rüsen, 2001: 253; Gergen, 2005: 101; Bøe, 1999: 19-23; Smith, 2009: 3; Ammert, 2015: 117-19, 121-4), but there is still a lack of empirical evidence supporting this notion. While previous research projects have presented important results of students' views on moral issues in history (see, for example, Barton and Levstik, 2009; Löfström, 2014), larger studies are required (Endacott and Brooks, 2018: 220-1).

The inter-temporal orientation in relation to moral issues is a starting focal point in this study, which aims to identify and analyse 15-year-old students' expressions of temporal orientation and personal moral reflections by studying their reasoning about interpretations of the past, understandings of the present and perspectives on a possible future. Temporal orientation means if, and how, people connect and interrelate the past, the present and the future. These interrelationships form a web, with reasoning, experiences, knowledge, interpretations and expectations connecting different time layers (Jeismann, 1979). Accordingly, temporal orientation is the central point of a historical consciousness, but a consciousness cannot be observed per se - how temporal orientation is expressed is more tangible. In this study, the temporal dimension is identified and analysed by exploring secondary school students' written responses to a task. Students were provided with an excerpt from Christopher Browning's (2017) book centred on the Second World War and the Holocaust, Ordinary Men: Reserve Police Battalion 101 and the Final Solution in Poland (originally published in 1992). The excerpt describes events leading up to the order of a massacre in the Polish village of Józefów in 1942. In this article, an analysis is presented of how one central element of historical consciousness - temporal orientation - can be conceptualized and operationalized. The analysis and subsequent results are based on a matrix developed for this study and based on the theoretical work of Rüsen $(2000,2001,2004)$ and Chinnery (2013) (see Table 1). While there has been other work carried out on student interpretations of Browning's work and this particular genocidal massacre (see, for example, Nilsen, 2016), this is the first analysis that examines relationships between historical consciousness and moral consciousness.

\section{Theoretical framework}

Developing a theoretical framework with the capacity to categorize and better understand students' expressions of temporal orientation in relation to moral reflection is a key output of this study. The framework developed combines two theoretical perspectives: Rüsen's (2004) four types of narrative typology and Ann Chinnery's (2013) model of how historical consciousness relates to and incorporates ethical and moral 
demands (in encounters with history) on humans. According to Rüsen (2004), historical consciousness can be described as a narrative competence based on, and with the ability to create, meaningful stories about interrelations between the past, the present and the future. His established typology with four types of narratives - traditional, exemplary, critical and genetic - can be applied to identify and analyse how historical consciousness can be expressed (Rüsen, 2004; see also Seixas, 2004: 22-3).

The first category, the traditional narrative, describes the past as eternal, permanent and evident. In this way of thinking, nothing changes, and the past may be repeated as sameness over time. The past is not challenged because there is no immediate need for interpretation. Although it is possible to make the past come alive, it happened in, and belongs to, the past. The second category is exemplary narrative, which stresses rules, patterns of life and codes of conduct as guiding principles for society and for people. This is the idea that historia magistra vitae est-people should learn lessons from the past for the present and the future. The third category of historical narrative is described by Rüsen (2004) as the critical type. The critical type takes a clear starting point in the present but does not make direct connections to historical events. The past is no longer understood as absolute and valid from our present point of view. This category indicates a historical consciousness that takes into consideration the fact that time changes, and that is why it is important to formulate a counterpoint or a critical history when considering the past. Alternative narratives offer relief or distance. In this category, the past is considered to be a more or less isolated time dimension. For the purposes of this study, the critical type also includes taking a critical stance to what happened in the past and dissociating from it. The fourth category, the genetic type, reflects the perception that the past is changing and inherently changeable, and is necessarily embedded in the always-vanishing present. This narrative type expresses the idea that change is natural when regarding the past. Genetic narratives show that every time period reflects what is unique for that era, and that different stories are told at different times. The present is a station of change between the past and the future (Rüsen, 2005: 15).

Chinnery (2013) nominates three main strands of historical consciousness that address and connect with ethical and moral demands on humans in the present and their relation to the past - to which we add for this study perspectives on the future. For this analysis, the three strands describe connections between the individual and interrelationships in and between temporal layers within a framing of moral aspects. The first is an existential strand, meaning that an individual considers and reflects on themselves and their life, grounded in the past and the future. There are ethical and moral preconditions for an individual's perceptions and interpretations. In the existential strand, relationships and interrelationships to the past are fundamental, and they put people in networked contexts where the perception and understanding of the self, relative to wider temporal contexts, are crucial. The second strand is cognitive (knowledge-based). Knowledge about the past can enable a factual interpretation and understanding of - for example-moral problems in the past, as well as in the present and the future. It will also help people analyse the past and make measured decisions about how to act - in the present and in the future. A narrative competence or ability forms the third strand, influenced by the work of Rüsen (2004) and Straub (2006). This competence is the ability to receive, interpret and transform narratives from the past into meaningful contexts (Chinnery, 2013: 254).

All three strands - existential, cognitive and narrative competence - are relevant for encounters with moral perspectives. A fourth strand proposed by Chinnery (2013) is an ethics of care. This ethical approach sees people in this context as caring for 
past moral actions. Ethics of care forms an important bridge between historical consciousness and moral consciousness, but for the purposes of the analytical approach selected for this part of the project, it is not possible to isolate an ethics of care from the other strands. A connection expressing caring for the moral actions of the past would necessarily also be based on knowledge-based relations or existential relations. This aspect is more applicable and able to be applied when specifically analysing how a moral consciousness in relation to the past is expressed. The strands provide a richer and more refined way to describe how people relate to moral perspectives or dilemmas in history. Narrative competence is the most advanced strand or type of historical consciousness, because it integrates both existential perceptions and practical knowledge-based abilities into a complex competence of meaning making. It often requires elaborated reasoning.

Rüsen's (2004) and Chinnery's (2013) typologies were selected to integrate into a matrix to enable an analysis of our data. Rüsen's (2004) model - our primary typology - has the capacity to grasp inter-temporal relations and also sense-making aspects of temporal dimensions. Historical narratives are charged with moral values and messages from, or manifested in, the past. These messages frame the narratives. Although Rüsen's (ibid.) typology could be used to analyse the narratives, in this study it is applied to identify and analyse students' answers to questions about relevance in messages from the past. Chinnery's (2013) strands enable moral content to be approached in interconnections and interrelations between the past, the present and the future. When merged, Rüsen's (2004) approach can make explicit Chinnery's (2013) narrative competence in the form of categories that capture variations in ways of mobilizing historical references in making value judgements, and how these things are interpreted by individuals - in the case of this study, secondary school students.

Students' responses were allocated to categories based on the prescriptive definitions of each item in our matrix (see Table 1). In addition, decisions were made about how to categorize student responses in terms of verbs used to describe what they discussed in their responses, including whether or not participants used verbs associated with higher-order thinking, such as those found in common student learning taxonomies, and comparative verbs. The content of student responses was also used to allocate them to a category when referring to the past, present and/or future.

To ensure integrity of data analysis, categories attributed to the qualitative data received from the students were first coded by two researchers and discussed, before a preliminary determination was made as to where to place the responses in the matrix. This quality assurance process was then checked again by two more researchers, who read the student responses as categorized by the first two researchers, and commented on the validity of their categorization. The final categorization was achieved through consensus by the four researchers.

\section{Methodological discussion}

This section details the starting points of an empirical study of students' temporal orientation via reflection in relation to a historical event concerning moral decisions. There are three important points to note. First, historical and moral consciousness involve mental processes that are not immediately observable; thus, the focus of the study is on how the school students who participated in the research project express perceptions of temporal interrelations in relation to moral reflections and motivations. Moral reflections can involve cognitively defining moral issues, but also making moral judgements (see, for example, Rest, 1979), and here, no distinction is made between 
Table 1: Combined theoretical typologies for analysing expressions of temporal orientation in relation to moral reflection

\begin{tabular}{|c|c|c|c|}
\hline $\begin{array}{l}\text { Chinnery's } \\
\text { (2013) strands } \\
\text { Rüsens's } \\
\text { (2004) types }\end{array}$ & $\begin{array}{l}\text { Existential strand } \\
\text { Relating to oneself, } \\
\text { to one's own } \\
\text { opinions, with } \\
\text { moral reasoning } \\
\text { or arguments, } \\
\text { human values. }\end{array}$ & $\begin{array}{l}\text { Knowledge- } \\
\text { based strand } \\
\text { Factual reasoning, } \\
\text { not necessarily with } \\
\text { moral reflections. }\end{array}$ & $\begin{array}{l}\text { Narrative } \\
\text { competence } \\
\text { Sense making, } \\
\text { explicit } \\
\text { contextualization, } \\
\text { past-present- } \\
\text { future is visible. }\end{array}$ \\
\hline Traditional & $\begin{array}{l}\text { 1. Reflections } \\
\text { of the past and } \\
\text { expectations of } \\
\text { the future. Relate } \\
\text { chronologically } \\
\text { to the past and } \\
\text { the future. Time } \\
\text { does sometimes } \\
\text { repeat itself and } \\
\text { sometimes times } \\
\text { change. Morality } \\
\text { as a heritage or an } \\
\text { obligation. }\end{array}$ & $\begin{array}{l}\text { 2. Individuals } \\
\text { could, based on } \\
\text { facts, identify } \\
\text { and describe } \\
\text { historical time and } \\
\text { moral issues as } \\
\text { continuities. }\end{array}$ & $\begin{array}{l}\text { 3. Individuals } \\
\text { identify and } \\
\text { interpret the past, } \\
\text { and moral values } \\
\text { from the past, as } \\
\text { continuous lines } \\
\text { through time. } \\
\text { Meaning making. }\end{array}$ \\
\hline Exemplary & $\begin{array}{l}\text { 4. Roots and } \\
\text { relations are } \\
\text { stressed. } \\
\text { Individuals could, } \\
\text { and should, learn } \\
\text { from the past. }\end{array}$ & $\begin{array}{l}\text { 5. Facts and } \\
\text { knowledge help } \\
\text { individuals to } \\
\text { interpret what is } \\
\text { worth bringing on } \\
\text { from the past. }\end{array}$ & $\begin{array}{l}\text { 6. Individuals } \\
\text { should apply and } \\
\text { relate to moral } \\
\text { messages from the } \\
\text { past as something } \\
\text { to learn from } \\
\text { or accept. }\end{array}$ \\
\hline Critical & $\begin{array}{l}\text { 7. Individuals' } \\
\text { deep-rooted moral } \\
\text { perceptions lead } \\
\text { them: (1) to say } \\
\text { that the narrative } \\
\text { is not relevant in } \\
\text { the present; ( } 2 \text { ) } \\
\text { to criticize what } \\
\text { happened in the } \\
\text { past; or ( } 3 \text { ) to } \\
\text { dissociate from } \\
\text { the past. }\end{array}$ & $\begin{array}{l}\text { 8. A factual } \\
\text { interpretation } \\
\text { could question, } \\
\text { dissociate from or } \\
\text { criticize (dismiss) } \\
\text { what happened in } \\
\text { the past (or what } \\
\text { happens in the } \\
\text { present). }\end{array}$ & $\begin{array}{l}\text { 9. Individuals } \\
\text { could analyse } \\
\text { what is not valid } \\
\text { in the present and } \\
\text { discuss why. } \\
\text { An expressed } \\
\text { ability to propose } \\
\text { counter-narratives. }\end{array}$ \\
\hline Genetic & $\begin{array}{l}\text { 10. Individuals } \\
\text { consider existential } \\
\text { aspects of } \\
\text { narratives from the } \\
\text { present, but also in } \\
\text { relation to the past } \\
\text { and perspectives } \\
\text { on the future. What } \\
\text { happened in the } \\
\text { past is connected } \\
\text { to the present and } \\
\text { what is to come. }\end{array}$ & $\begin{array}{l}\text { 11. Individuals } \\
\text { could interpret } \\
\text { and prove what is } \\
\text { similar and what } \\
\text { is different from } \\
\text { the past (and } \\
\text { what seems to } \\
\text { be important in } \\
\text { the future). } \\
\text { Individuals could } \\
\text { understand moral } \\
\text { issues in relation } \\
\text { to transformations } \\
\text { in society. }\end{array}$ & $\begin{array}{l}\text { 12. Individuals } \\
\text { could interpret } \\
\text { and understand } \\
\text { what previous } \\
\text { actions really } \\
\text { meant in the past } \\
\text { and why, but also } \\
\text { how the future } \\
\text { might be, and } \\
\text { how the past and } \\
\text { the present will } \\
\text { be described in } \\
\text { the future. }\end{array}$ \\
\hline
\end{tabular}


these two kinds of approaches to moral issues. Second, secondary school students were not studied continuously in an ethnographical way. Instead, students were asked to respond to stimulus material that connected with issues that are theoretically relevant to historical and moral consciousness. Third, this research is interested in identifying qualitative differences between individual adolescents' responses, but also in the generally shared features in their responses.

Questions and questioning are crucial to learning, to knowing and to explaining something (Ricoeur, 1984: 239; Rüsen, 2004: 19). Explicit questioning is key to being able to analyse students' responses in accordance with ideas of temporal orientation. One disadvantage to using this method is that the questions could unduly influence the students' answers. However, as this study is interested in aspects of their reasoning rather than the content or factual basis of their answers - explicit questions concerning temporal orientation are suitable and even preferred. Rüsen (2001) describes two ways in which questions can arise to stimulate or activate historical consciousness. First, they can arise from something empirically present, for example, artefacts, commemorations, narratives or traditions. Second - and this is the focus in this study - questions can arise from rapid unexpected turning points in society or in private life (ibid.: 253). These kinds of borderline events trigger questions about why the turning points have arisen, about what they mean, about what will or what might happen, and about what could have happened already (Andersson Hult, 2016: 23).

In qualitative research, there are many ways that data can be analysed, and various lenses can be applied to attain a deeper understanding of participants' responses. Because our focus is on the intersections of moral consciousness and historical consciousness, in this research we chose not to take a social psychological or a cognitive approach to data analysis, but to examine how students engaged in their reading of historical texts, with a focus on students' reactions based on temporality and moral dimensions.

Regarding the design of the study, it could be argued that a limitation is that, given the varying written literacy proficiency of students, some students may have had more difficulty than others in expressing their views. Furthermore, as the research was undertaken in the context of history lessons, this may have sensitized the students in a different way than asking them to do the questionnaire in a non-related class.

\section{Conducting the research}

Students were provided with an excerpt from the book by Christopher Browning, Ordinary Men: Reserve Police Battalion 101 and the Final Solution in Poland (originally published in 1992), a historical study of the operations of a German police battalion in Poland in 1942-3. The extract - adapted from pages 55-7 of the book (Browning, 2017) describes how the commander of the battalion, Major Trapp, received orders to commit genocidal murder of the Jewish inhabitants of the Polish village of Józefów. The extract tells how the men in the battalion reacted to the task, and it details Major Trapp's offer that the elderly men of the battalion did not have to take part in direct killing if they did not wish to. The researchers edited the text slightly so that the student participants were not distracted by technical terminology or other information superfluous to the task at hand. The purpose was to present to the students a specific, historical situation, selected due to its ethical complications and morally challenging nature.

Browning's text was chosen based on the aim of our larger study, the objective of which is to investigate students' expressions of temporal orientation by studying their reasoning about interrelations between dimensions/layers of time, and not their 
factual or content knowledge. Accordingly, students were given a written excerpt within a historical context that was familiar to them. Such an infamous historical event was selected as a way to eliminate the risk of students saying that they did not know anything about the situation or that they did not understand the context. By Year 9, Finnish and Swedish students have studied the Second World War and the Holocaust. Also, Nazi officers and soldiers are often described as unambiguously reckless and aggressive. In this excerpt, the expected view of them is suddenly changed, and some of the members of the Reserve Police Battalion are presented counter to the traditional expectation when they chose not to participate in killing innocent people. This counter-narrative provides an opportunity for students to reflect on the situation and their understanding of the messages within the narrative.

Following their reading of the text, 15-year-old Finnish and Swedish secondary school students answered a set of eight open-ended questions centring on historical and moral reflections. This article addresses two of the eight questions posed to student participants, Questions 2 and 3. Question 2 read: 'Does the narrative send a message to you personally? Explain your answers.' The purpose of this question was to investigate if and how students relate to and interpret a historical text. The analysis is then able to determine whether they find a message in the text and perceive it as relevant, valid and worth bringing into the present, or if they think it should be relegated to the past with no connection to the present or to the future. Question 3 read: 'Do you think that a similar situation could occur in Europe today or in the future. Why/why not?' This question was framed in order to: (1) investigate how the students reasoned and argued about the future, in relation to the past from a present-day perspective; and (2) to study whether student participants refer to or relate to moral principles when considering this. The questions were designed to elicit responses that expressed students' views on continuity and discontinuity between the past, the present and the future, including whether or not the types of moral challenge faced by historical actors were perceived as relevant today or for the future. Thus, the questions addressed students' abilities to think in terms of diverse temporal interconnections, and to use their knowledge of the past to interpret the world of today and to imagine possible futures.

This article reports on responses from 220 participants, made up of 109 females, 104 males and 7 students who did not want to disclose their gender. One student answered only Question 2 and six students answered only Question 3. Two students did not answer either of the two questions. Because some questions were not answered by all student participants, 401 answers have been categorized for analysis. The selection of students is not statistically representative of wider populations. They attend a variety of schools in terms of socio-economic status and geographical location, but they were not selected as being nationally representative of the number of females and males, or the number of students born in Finland or Sweden. Areas included small communities, medium-size towns and large cities. History is a mandatory subject from Year 5 in Finland and from Year 1 in Sweden in compulsory school. Due to the national curricula and syllabuses, all students in Finland and Sweden study the Second World War and the Holocaust, which is explicitly addressed in the syllabus, usually in Year 8 (Finnish National Agency for Education, 2016; Swedish National Agency for Education, 2018).

The students completed the activity by accessing a password-protected digital platform during a history lesson, reading the adapted extract from Browning's (2017) book, and responding to the questions. Students' responses were then collated and analysed according to the theoretical profiles listed in the matrix categories combining Rüsen's (2004) and Chinnery's (2013) typologies (see Table 1). Responses were categorized based on a holistic reading of their responses, rather than on individual 
words, which could potentially be taken out of context, so that an understanding could be gained of the students' temporal-orientation expressions. After this preliminary analysis, the two answers from each participant were read together, contextually, in order to identify interpretations and aspects that might have been missed in the initial separate readings. In the Findings section, we provide examples of how the coding of answers was carried out.

\section{Findings}

First, we present a quantitative overview of the distribution of the participants' answers (see Table 2). Second, we discuss participants' arguments, how they were interpreted and coded, and how the participants express different types of temporal orientation. Third, we analyse the students' moral reflections, and the relations between temporal orientation and moral reflections.

Table 2: Distribution of answers in the combined theoretical typologies of temporal orientation in relation to moral reflection (number of answers, and percentage of the total number of answers)

\begin{tabular}{|c|c|c|c|}
\hline $\begin{array}{l}\text { Chinnery's } \\
\text { (2013) strands } \\
\text { (2004sens's types }\end{array}$ & $\begin{array}{l}\text { Existential strand } \\
\text { Total: } 38 \%\end{array}$ & $\begin{array}{l}\text { Knowledge- } \\
\text { based strand } \\
\text { Total: } 58 \%\end{array}$ & $\begin{array}{l}\text { Narrative } \\
\text { competence } \\
\text { Total: } 4 \%\end{array}$ \\
\hline Traditional & $\begin{array}{l}\text { Question 2: } 12 \\
\text { Question 3: } 35\end{array}$ & $\begin{array}{l}\text { Question 2: } 32 \\
\text { Question 3: } 40\end{array}$ & $\begin{array}{l}\text { Question 2: } 2 \\
\text { Question 3: } 3\end{array}$ \\
\hline Total: $31 \%$ & $\begin{array}{l}\text { Total } \\
\text { answers: } 47 \text { (12\%) }\end{array}$ & $\begin{array}{l}\text { Total } \\
\text { answers: } 72(18 \%)\end{array}$ & $\begin{array}{l}\text { Total } \\
\text { answers: } 5 \text { (1\%) }\end{array}$ \\
\hline Exemplary & $\begin{array}{l}\text { Question 2: } 60 \\
\text { Question 3: } 1\end{array}$ & $\begin{array}{l}\text { Question 2: } 37 \\
\text { Question 3: } 4\end{array}$ & $\begin{array}{l}\text { Question 2: } 4 \\
\text { Question 3: } 0\end{array}$ \\
\hline Total: $26 \%$ & $\begin{array}{l}\text { Total } \\
\text { answers: } 61 \text { (15\%) }\end{array}$ & $\begin{array}{l}\text { Total } \\
\text { answers: } 41 \text { (10\%) }\end{array}$ & $\begin{array}{l}\text { Total } \\
\text { answers: } 4(1 \%)\end{array}$ \\
\hline Critical & $\begin{array}{l}\text { Question 2: } 23 \\
\text { Question 3: } 6\end{array}$ & $\begin{array}{l}\text { Question 2: } 10 \\
\text { Question 3: } 39\end{array}$ & $\begin{array}{l}\text { Question 2: } 3 \\
\text { Question 3: } 1\end{array}$ \\
\hline Total: $21 \%$ & $\begin{array}{l}\text { Total } \\
\text { answers: } 29 \text { (7\%) }\end{array}$ & $\begin{array}{l}\text { Total } \\
\text { answers: } 49 \text { (13\%) }\end{array}$ & $\begin{array}{l}\text { Total } \\
\text { answers: } 4 \text { (1\%) }\end{array}$ \\
\hline Genetic & $\begin{array}{l}\text { Question 2: } 6 \\
\text { Question 3: } 8\end{array}$ & $\begin{array}{l}\text { Question 2: } 3 \\
\text { Question 3: } 68\end{array}$ & $\begin{array}{l}\text { Question 2: } 1 \\
\text { Question 3: } 4\end{array}$ \\
\hline Total: $22 \%$ & $\begin{array}{l}\text { Total } \\
\text { answers: } 14 \text { (3\%) }\end{array}$ & $\begin{array}{l}\text { Total } \\
\text { answers: } 71 \text { (18\%) }\end{array}$ & $\begin{array}{l}\text { Total } \\
\text { answers: } 5(1 \%)\end{array}$ \\
\hline
\end{tabular}

Note: Total number of answers: 401; number of answers to Question 2: 193; number of answers to Question 3: 208

Alphanumeric codes were used to identify participants: a number was assigned to each student, and a letter represents gender ( $F$ for female and $M$ for male; no student identified as anything other than male or female in the demographic questions in the 
sample selected for this article). In this article, we do not analyse potential similarities and differences between gender/sex, nationality, or geographical background.

\section{Temporal interrelations: Question 3 - relevance for the present and the future}

Relating to Question 3 - 'Do you think that a similar situation could occur in Europe today or in the future. Why/why not?' - the two most common types of temporal interrelations in the answers were the traditional type and the genetic type, representing approximately 35 per cent of responses each. The traditional type is the base-level way for students to discuss if a specific event in the past could occur in the present or in the future, because it primarily uses a chronological approach. In the traditional type of responses, students related to the past in a non-problematic way, asserting that what had happened probably either will happen or will not happen again. The answers in this category are mainly non-reflective when it comes to discussing transformations of time, and they therefore follow a line of continuity, assuming that similar things might or might not occur again in future.

In a response that can be categorized as traditional, Student $157 \mathrm{~F}$ makes a tentative connection between the situation in the text and the present day by writing in response to Question 3:

Yes, of course, we are people and if one thing has happened once, it can surely happen again. I mean if you tie your shoe and the knot goes up, it will surely go up several times before you learn to do double knot.

The answer indicates that the past will in all probability repeat itself, as easily as tying up a shoelace; humans remain the same and people just act and react, which does not express a very refined understanding of temporal orientation. It is categorized as traditional because Student $157 \mathrm{~F}$ identifies the factual context, but does not discuss or problematize the similarities and differences between the past, the present and the future. She seems to regard temporal connections as given and unchangeable.

Only five student answers were categorized in the exemplary type of historical consciousness in response to Question 3. The critical type was more frequent, with 25 per cent of the answers within this category. For example, the response from Student 228M reads:

We have not had war in Europe in 70 years. According to me there is more and more peace in the world.

The student starts his response by stating that (according to his perspective) there has been no war in Europe for 70 years, asserting that the world is more peaceful. The connection to the past is not relevant for him when he considers potential similarities or differences in the present or in the future. The student dissociates from the past by implying that it is not relevant in a future scenario.

Concerning the genetic type of historical consciousness, the frequency of students in this category was higher. An explanation for this high result is that Question 3 asked students to reflect explicitly on whether similar situations might occur in the future. Approximately 35 per cent of the participants delivered reflections and arguments in which the past was interwoven in the discussion and the assessment of the situation today and their expectations of the future. The genetic type is a complex, elaborated way of reasoning, and it involves thinking of and between different dimensions of time, 
demonstrating temporal orientation, and reflecting on differences and transformations of the issues. The genetic type of responses most frequently occurred in responses from students about whether they believe that similar situations could occur in the present or in the future. To illustrate this category, in a very detailed answer (unlike other participants' responses), Student 76F wrote:

Both yes and no. Given the unrest in Europe today in politics, I would not see it as completely impossible unfortunately. Right-wing extremist parties may have greater influence, e.g. the Swedish Democrats, despite their xenophobic and women-oppressive politics, or the Danish Labour Party, who has now banned the burqa in public places, that is, women's oppression in the toe tips [a Swedish expression that means, more or less, 'to the extreme' or 'to the edge', depending on context]. A ban on the burqa does not result in women's oppression within this culture ceasing, but merely makes the women who actually have the worst conditions be forced to stay home and their opportunities to have their own life go up in smoke. I think it is totally unreasonable that white, rich, highly educated men should decide on these women's bodies and lives. In this situation, one must listen to the WOMAN behind the burqa. The Nordic Resistance Movement is allowed to stand beside RFSU [the Swedish Assocation for Sexuality Education] at the Almedalsveckan in Visby, and the police are instructed to protect the Nazis, not the vulnerable. [Almedalsveckan is an annual week-long event in July, considered the most important event in Swedish politics. Political parties, organizations and members of the public who are interested in social issues meet in Visby for networking, discussions and seminars.] On the other hand, parties to the left grow too, which means that the two more extreme political types are growing and a 'gulf' is growing. I think like this: the more people who settle in either extreme, right or left, the more who disagree in politics. The more disagreeable, the more anxious it becomes and the risk of major conflicts increases. I myself think it is completely unacceptable just in view of this story that Nazism is still living in our society today. We saw how fast Hitler gained influence in Germany. Similarly, the right-wing extremist parties gain more influence in Sweden, which scares me. How can it be legal and accepted by society to be a racist, a Nazi or anti-Semitic?

In this extended answer, Student 76F presented reasoning that was advanced and that expressed a deep engagement with, and knowledge of, human rights and democratic issues. It is clear that the excerpt from Browning's (2017) book resonated with her, and that she was able to communicate clearly her moral reasoning, linking history with present-day politics. Here, her temporal orientation was sophisticated, as her discussions integrated and switched between the past, the present and the future, as she used facts from the past as something people in the present had to bear in mind when engaging with current sociopolitical issues. Existential aspects were central in her reasoning about how human values were oppressed in the past and how they must be protected in the future, while also recognizing present-day threats to freedom and democracy. The genetic type of narrative catches these interrelations in time, and Student 76F presented a discussion on non-democratic tendencies in contemporary society. She used the fact that Nazism is still present in society as a reference for how the situation in Europe today could unfold in the future when she discussed her fear of political polarization and xenophobic perceptions and activities. 


\section{Temporal interrelations: Question 2 - personal message}

Responding to Question 2 - 'Does the narrative send a message to you personally? Explain your answers.' - participants described in different ways, and with different motivations, what message they took from the extract, and their reactions were just as varied. The dominant category of historical consciousness was the exemplary category (52 per cent of responses), followed by the traditional type (24 per cent of responses) and the critical type (18 per cent of responses). Many students interpreted the message in the text as individuals having choice or having the option to follow their own will. The students who related to the exemplary type in their responses often stated that the men who stepped out of the line and did not participate in the executions did the right thing, and that this is a message to apply to current and future contexts. In such exemplary reasoning, students interpreted a positive and hopeful message for the future.

Student 63F referred to the soldiers who refused to take part in the execution:

In this case, I think that the moral for me today would be the few people who opposed and refused the task of participating in the event. I think it meant to me that you should not lose yourself but stick to what you think is right and what feels good in your stomach.

This participant interpreted the story as a historical moral message to learn from the actions of other individuals. It gave her a type of motivation to act ethically in the present day. She related the position of the soldiers to her own moral principles by writing, 'you should not lose yourself but stick to what you think is right and what feels good in your stomach'.

There were also several students who emphasized that what happened during the Nazi regime was terrible, and they expressed a strong dissociation from it. Student $165 \mathrm{~F}$ illustrates the critical perspective, writing in response to Question 2:

No, I personally do not think so, mostly that it is wrong to do this. I think a little more that it is like a little story what happened earlier.

This student focused on the fundamental evil activity occurring in the narrative, but she did not personally take on or connect with any message that could come out of the text, and she implied that the narrative of what happened was not very relevant for her current life. The differences could mean that different individuals interpreted different aspects of what they perceive, but it might also be a result of their ability to read and comprehend a difficult and complex text, which illustrates a potential limitation of the study. In this analysis, we are aware that the immediate context was about preparations for the selection and execution of Jewish people living in a rural village. To identify a deeper message about how some of the soldiers reacted, and how Major Trapp (the commander of the battalion) handled the situation, requires a careful and closer reading, which could be a literacy challenge for some students.

In some respects, the pattern of a majority of responses to Question 2 falling into the exemplary type is what we might expect. The excerpt that the students read expresses deep moral and human issues, and it would be difficult for a reader's reactions to be neutral or indifferent. However, there were some students (22 per cent) who reacted by indicating that their reading of the extract was that certain things happened in the past, describing a linear connection over time. They did not communicate if or how the message meant something to them personally, now or in relation to the future. 


\section{Moral approach by existential and knowledge- based strands}

More than 50 per cent of the answers to Question 3 related to factual knowledge (categorized using Chinnery's (2013) typology) about what happened in the past and the preconditions for society today. The students applied their knowledge when interpreting and discussing perspectives on the future. There could have been moral considerations behind the answers. However, they were not always explicit, nor were they used as main arguments, as was the case with more than 30 per cent of students' responses. For example, Student 130M's response to Question 3 provided an example of existential or moral references mentioned in subordinate clauses, not in the main arguments:

Yes in Russia. Putin wants to take back what was Russia's (imperial Russia). The Soviet Union did the same to people but in worse ways, such as letting people starve. I think Russia will at least be the reason why it will be such a disaster in Europe if it now happens because they are the country that wants their 'land' back, at any cost.

This answer could be defined as relating to existential arguments, as well as to factual and cognitive-based arguments. However, his main argument was the reference to historical interpretation, and accordingly the answer was coded in the cognitive strand. This student described, from within a historical context, what he saw as a possible scenario. The factual arguments dominated, but he implied that it would be a disaster, and he signalled his opinion in how he interprets Russian conduct, today as well as in the past. He was applying his broader knowledge of historical actions taken by Russia and the USSR throughout the twentieth century to the extract, and describing how Russia could 'be such a disaster in Europe', drawing mitigated parallels between Nazi Germany and Russia in the present day and in what he saw as a likely future.

Existential arguments, in which students discussed questions relating to personal and moral perceptions of right and wrong, were especially frequent in answers to Question 2 (52 per cent of responses) - 'Does the narrative send a message to you personally? Explain your answers.' When students reflected on this question, the most common answer was a combination of the exemplary type (Rüsen, 2004) and the existential strand (Chinnery, 2013). The question was personal, and it implicitly encouraged students to go beyond what might be right or wrong, and to relate the case to their experiences, their previous or background knowledge, and their own opinions (see also Sellman and Barr, 2009: 19-20). In several answers, students' reasoning took its starting point in what seemed to be deep-rooted perceptions of how people should and should not treat each other. Strongly stressed reactions against the Nazi regime and the genocide of the Jewish people made students dissociate from events as described in the extract. Similar reactions, but aiming to learn from the soldiers who stepped out of the line and refused to take part in the killing, characterized the answers in the exemplary type, with participants using the courage of the men as a role model for behaviour.

In our research, we also made use of Chinnery's (2013) narrative competence strand as an elaborated expression of a historical consciousness. This strand is complex and accommodates reasoning that connects dimensions of time to each other, and that explores how relations between them make meaning in people's lives at different times. Our questionnaire data is open for this kind of interpretation, but the answers are often short, with participants not usually grasping the broader temporal context. 
The narrative competence strand is not frequent enough to be used in analysing the specific answers on which this article focuses. However, there are a few examples that show how the students clearly discussed the interrelations between times, how content could be understood differently at different times, and what that meant when they tried to interpret the content in the present day. For example, Student 112F asserted that a similar situation could occur in the future, writing:

It could. Not similar to what exactly happened, that they would kill people, but similar in the way that one is manipulated to believe that one has one's own will, it is difficult to notice, but easy to see afterwards. An exact such situation is probably difficult, because it has happened before, and people decided afterwards that it was wrong.

This student described a scenario where people think that they have their own free will, but then expanded on this to state that, in reality, they are being manipulated. One way to interpret this response is as suggesting that she is self-identifying fears for a future where people will be misled, as can be seen in her statement, 'one is manipulated to believe that one has one's own will, it is difficult to notice, but easy to see afterwards'. This student also discussed how actions in the future will be regarded afterwards - that is, in the future's future - an elaborated way of reasoning about interrelations between time layers as temporal orientations. This discussion is based on her interpretation of the past. In this way, Student 112F expressed her narrative competence, meaning that she understands that activities and actions could be regarded differently in different times. She expressed a genetic type of narrative, in which the past, the present and the future were interrelated.

\section{Discussion and concluding words}

Students' reasoning when answering questions after reading the extract provide an empirical foundation to reflect on how their temporal orientation as a form of historical consciousness was expressed. The questions were explicit, but they were open-ended, and they prompted students to reflect on whether a similar situation could happen today or in the future and how (if at all) they perceived a message in the narrative as applicable to their present-day lives. Responses were analysed by categorizing them against the two interconnecting theoretical dimensions of the matrix (see Table 1), one dimension showing how the responses interrelated different layers of time to each other (as per Rüsen's (2004) typology), and the other one showing how responses approached and reflected on the moral dimension (as per Chinnery's (2013) three strands).

While the empirical study comprised written answers from 220 Finnish and Swedish students, it is not statistically representative for all 15-year-old students in Finland and Sweden. The aim of this study was to identify and analyse students' expressions of temporal orientation in relation to moral reflection, as part of a heuristic ambition to explore the intersections of historical consciousness and moral consciousness in high-school students on a topic that they have formally learned about in the classroom.

Overall, the genetic and the traditional types from Rüsen's (2004) typology dominated the students' reasoning about whether similar situations could occur in the future. In the traditional type category, students related to the past in a nonproblematizing way, with an assumption that what had happened would probably happen or not happen again. The answers were mainly non-reflective when it came 
to discussing transformations of time. The high frequency of students expressing a genetic type response (about 35 per cent of responses) was notable, because the genetic type is complex and involves reflection on continuity and change, similarities and differences and, not least, awareness of the existence of different views at different times. A high percentage of the students provided reflections and arguments about how the past was interwoven in the discussion, and about the assessment of current sociopolitical situations and the expectations that student participants had about the future.

In the critical type of historical consciousness category, students discussed how the oppression and execution of Jewish people was terrible, but they observed that it was in another time and in a past sociopolitical context and, as such, they dissociated today's society from that past. In these examples, students discussed their position and their reflections on facts, and they put their trust in people and societies in the future developing by dissociating from what had happened in the past.

Many of the students' answers to Question 2 focused on the battalion commander, Major Trapp, giving his soldiers the opportunity not to participate in the execution of Jewish people. The question elicited personal reflections and arguments, and just over 50 per cent of the answers were characterized in the exemplary type, because students identified the main message as being that it was possible to follow one's own will and to refuse to do things that one believed were morally or ethically wrong. Students reflected on the message from the past to the present, but they did not explicitly reflect on whether the message was valid in different times. This could indicate: (1) that the primacy of the present was paramount to them in their interpretation; (2) that they posited a linear connection between the past and the present; or (3) that they were not asked to explain that aspect, so they did not do so. The students interwove different temporal layers, but not always in dialogue with the conditions in the past. While 20 per cent of participants did not consider the extract on a personal level, the message received by them was that certain things happened in the past, that is, they understood them through a linear connection over time. However, a convincing finding is that students had the ability to interrelate temporal dimensions when asked. For those sceptical about students' abilities to undertake such a task, and who might therefore encourage its avoidance in the classroom, this demonstrates that students when provided with the opportunity to do so - are able to respond in a sophisticated, or complex, manner that demonstrates skills in interlinking temporal dimensions.

In the analysis of how a moral approach was expressed by the students, Rüsen's (2004) types of historical consciousness were combined with the kind of motives and arguments that give fuel to the students' reasoning, as per Chinnery's (2013) strands. More than 50 per cent of the total number of responses related to factual knowledge about what happened in the past and its relevance for society today, possibly indicating the importance that the participants placed on historical knowledge, despite the questions not necessarily requiring any specific historical knowledge. The students used their previous knowledge to identify and interpret what happened in the past, and to discuss factual perspectives on the future. Although there might have been moral considerations behind the answers, they were not always explicit, and they were not the main arguments. There could be several explanations for this. First, students are more familiar with factual reasoning, putting empathy or moral aspects aside. This has been the traditional and established way of teaching, learning and presenting history at school. Second, the question of whether a situation similar to the one in the extract could occur again opens up opportunities for a knowledge-based discussion. These are also indications that personal moral references, as well as changing views of 
moral perceptions and issues, were treated as part of factual considerations by more than 30 per cent of the students.

When students reflected on what message the narrative sends to them (Question 2), the most common answer profile was a combination of the exemplary type (Rüsen, 2004) and the existential (here including personal and moral aspects) strand (Chinnery, 2013), with 52 per cent of responses containing existential arguments. The question was personal, and it stimulated students to discuss more than what might be right or wrong, and also to relate to their experiences, their previous knowledge and their own opinions (see also Sellman and Barr, 2009: 19-20). In several answers, the reasoning took its starting point from what seemed to be deep-rooted perceptions of how people should and should not treat each other.

Classroom teachers know their students, and know how they learn best. They are at the 'coalface', teaching them and interacting with them, usually almost daily. However, this article can assert several general findings:

- High-school students can communicate their understanding of the nuances of human behaviour in history. This may help teachers to plan lessons, knowing that their students have the capacity to see historical events beyond the black and white, as they are frequently portrayed in the news and media.

- Students can readily connect present-day events (particularly the political) with the past, and this can be of interest to high-school students. Knowing this, teachers could plan lessons to provide an interesting hook to engage students, especially when teaching about traumatic pasts and difficult histories.

- Even when students are not asked explicitly to do so, they can draw on historical factual knowledge that they already have - their background knowledge - in their responses. Teachers may use this understanding of their students' world to construct learning experiences for them that connect with their knowledge and/or experiences.

- For teachers, the results suggest that it can be beneficial and valuable, especially when teaching about difficult histories and traumatic pasts, to provide opportunities for students to question ethical implications and moral dimensions in history. Doing so could bring a more in-depth understanding of history and historical thinking. For teachers to do this, professional support will be required, so that teachers are equipped with the pedagogical skills to approach difficult questions in the history classroom.

One important finding was that the most common combinations of answers were on existential foundations. Students were able to relate to (and learn from) the past when it came to personal and moral reflection, but they also used knowledge-based explanations of changeable contexts, or dissociated from the past when it came to discussing potential future developments. Participant responses in this study demonstrate that for students to be able to articulate a position of elaborated moral reasoning of historical topics, they must be provided with opportunities to integrate knowledge and content from historical evidence. The students who based their reasoning on existential and moral foundations and experiences neglected neither the factual historical context nor their previous knowledge. At the same time, moral and existential aspects were implicitly present in several answers where students' main explanations and arguments were based on factual knowledge. This is an important finding because there is a risk that moral reasoning is, by its nature, more or less based on (and biased by) the context of the students' lives in the present. In this study, the interlinking from both the existential and the knowledge-based positions was present 
and palpable. A historical factual foundation is important, but the type of historical consciousness affects (and is affected by) how strong an existential and meaningful thread there is between a person and their relationship to the past. This interlinking strengthens the hypothesis of the importance of investigating the intersections of historical consciousness and moral consciousness in educational settings.

\section{Notes on the contributors}

Niklas Ammert, PhD, is a professor of history with a special focus on educational science and history didactics at Linnaeus University, Sweden. Since 2014, he has been affiliated as an international collaborator at HERMES, University of Newcastle, Australia. His research mainly focuses on history teaching, history education and the uses of history - how individuals and groups encounter, interpret and communicate history at school, in higher education, in politics and in other cultural and societal contexts.

Heather Sharp, PhD, is an associate professor at the School of Education, University of Newcastle, Australia, the Convenor of the History Network for Teachers and Researchers (HNTR) and the Special Issues Editor of Historical Encounters. Her current research investigates the teaching of national history, especially through outbound mobility experiences, the influence of public history in teaching, historical representations in school curricula, particularly textbooks, and examines the written and visual texts in picture books that deal with conflict.

Jan Löfström, PhD, is an associate professor in social studies education at the University of Turku, Finland. He has researched, among other topics, young people's historical consciousness in the context of their view of historical responsibility. He is also editor of the multidisciplinary collection of articles, Voiko historiaa hyvittää? ('Can history be repaired?', Gaudeamus Helsinki University Press, 2012).

Silvia Edling, PhD, is a professor in curriculum studies at the University of Gävle, Sweden, and is a history teacher in upper secondary school. Her research interests include history didactic/didaktik, teacher professionalism, and conditions in and for education. Her most recent publication, with J. Liljestrand, is 'Let's talk about teacher education! Analysing the media debates in 2016-2017 on teacher education using Sweden as a case' (Asia-Pacific Journal of Teacher Education, 2019).

\section{References}

Alvén, F. (2017) Tänka rätt och tycka lämpligt: Historieämnet I skärningspunkten mellan att fostra kulturbärare och förbereda kulturbyggare (Skrifter med historiska perspektiv, 17). Malmö: Malmö Universitet.

Ammert, N. (2010) 'To bridge time: Historical consciousness in Swedish history textbooks'. Journal of Educational Media, Memory and Society, 2 (1), 17-30. Online. https://doi.org/10.3167/ jemms.2010.020102

Ammert, N. (2015) History as Knowledge: Ethical values and meaning in encounters with history. Frankfurt: Peter Lang.

Andersson Hult, L. (2016) Historia i bagaget: En historiedidaktisk studie om varför historiemedvetande uttrycks I olika former (Umeå Studies in History and Education, 15). Umeå: Umeå Universitet.

Angvik, M. and Von Borries, B. (eds) (1997a) Youth and History, Volume A: Description. Hamburg: Körber Stiftung.

Angvik, M. and Von Borries, B. (eds) (1997b) Youth and History, Volume B: Documentation. Hamburg: Körber Stiftung.

Barton, K. and Levstik, L. (2009) Teaching History for the Common Good. New York: Routledge. 
Bøe, J.B. (1999) Å fortelle om fortiden: Fortellingen i historie- og samfundsundervisning. Kristiansand: Høyskoleforlaget.

Browning, C. (2017) Ordinary Men: Reserve Police Battalion 101 and The Final Solution in Poland. Originally 1992. London: Penguin.

Chinnery, A. (2013) 'Caring for the past: On relationality and historical consciousness'. Ethics and Education, 8 (3), 253-62. Online. https://doi.org/10.1080/17449642.2013.878083

Clark, A. and Peck, C.L. (eds) (2019) Contemplating Historical Consciousness: Notes from the field. New York: Berghahn Books.

Colby, S.R. (2008) 'Energizing the history classroom: Historical narrative inquiry and historical empathy'. Social Studies Research and Practice, 3 (3), 60-9.

Cotkin, G. (2008). 'History's moral turn'. Journal of the History of Ideas, 69 (2), 293-315. Online. https://doi.org/10.1353/jhi.2008.0011

Edling, S. and Sharp, H. (2018) 'Exploring the link between historical consciousness and moral consciousness: Motivations, epistemological assumptions and moral themes'. Paper presented at the AARE Conference, Sydney, December.

Endacott, J.L. and Brooks, S. (2018) 'Historical empathy: Perspectives and responding to the past'. In Metzger, S.A. and MacArthur Harris, L. (eds) The Wiley International Handbook of History Teaching and Learning. New York: Wiley-Blackwell, 203-27.

Finnish National Agency for Education (2016) Grunderna för läroplanen för den grundläggande utbildningen 2014. Online. www.oph.fi/sv/utbildning-och-examina/grunderna-laroplanen-dengrundlaggande-utbildningen (accessed 13 July 2020).

Foster, S.J. and Yeager, E.A. (1998) 'The role of empathy in the development of historical understanding'. International Journal of Social Education, 13 (1), 1-7.

Gergen, K.J. (2005) 'Narrative, moral identity and historical consciousness: A social

constructionist account'. In Straub, J. (ed.) Narration, Identity and Historical Consciousness. New York: Berghahn Books, 99-219.

Jeismann, K.-E. (1979) 'Geschichtbewusstsein'. In Bergmann, K., Fröclich, K., Kuhn, A., Rüsen, J. and Schneider, G. (eds) Handbuch der Geschichtsdidaktik. Düsseldorf: Schwann, 42-5.

Karlsson, K-G. (2016) 'Making sense of lessons of the past: Theoretical perspectives on historical learning'. In Thünemann, H., Elevert, J., Gunderman, C. and Hasberg, W. (eds) Begriffene Geschichte - Geschichte begreifen. Frankfurt: Peter Lang, 101-26.

Kölbl, C. (2009) 'What can a developmental psychology of historical consciousness look like?' In Martens, M., Hartmann, U., Sauer, M. and Hasselhorn, M. (eds) Interpersonal Understanding in Historical Context. Rotterdam: Sense Publishers, 81-96.

Löfström, J. (2014) 'How Finnish upper secondary students conceive transgenerational responsibility and historical reparations: Implications for the history curriculum'. Journal of Curriculum Studies, 46 (4), 515-39. Online. https://doi.org/10.1080/00220272.2013.859301

Milligan, A., Gibson, L. and Peck, C.L. (2018) 'Enriching ethical judgments in history education'. Theory \& Research in Social Education, 46 (3), 449-79. Online. https://doi.org/10.1080/00933104. 2017.1389665

Mommsen, W.J. (2000) 'Moral commitment and scholarly detachment: The social function of the historian'. In Leersen, J. and Rignet, A. (eds) Historians and Social Values. Amsterdam: Amsterdam University Press, 45-55.

Nilsen, A.P. (2016) 'Navigating windows into past human minds: A framework of shifting selves in historical perspective taking'. Journal of the Learning Sciences, 25 (3), 372-410.

Online. https://doi.org/10.1080/10508406.2016.1160830

Rest, J. (1979) Development in Judging Moral Issues. Minneapolis: University of Minnesota Press.

Ricoeur, P. (1984) Time and Narrative: Volume I. Chicago: Chicago University Press.

Rosenzweig, R. and Thelen, D. (1998) The Presence of the Past. Popular uses of history in American life. New York: Columbia University Press.

Rüsen, J. (2000) 'Historical objectivity as a matter of social values'. In Leersen, J. and Rigney, A. (eds) Historians and Social Values. Amsterdam: Amsterdam University Press, 57-76.

Rüsen, J. (2001) 'Holocaust, memory and identity building: Metahistorical considerations in the case of (West) Germany'. In Roth, M. and Salas, C. (eds) Disturbing Remains: Memory, history and crisis in the twentieth century. Los Angeles: The Getty Research Institute Publications Program, 252-70.

Rüsen, J. (2004) 'Historical consciousness: Narrative structure, moral function, and ontogenetic development'. In Seixas, P. (ed.) Theorizing Historical Consciousness. Toronto: University of Toronto Press, 63-85.

Rüsen, J. (2005) History: Narration, interpretation, orientation. New York: Berghahn Books. 
Seixas, P. (2004) 'Introduction'. In Seixas, P. (ed.) Theorizing Historical Consciousness. Toronto: University of Toronto Press, 10-16.

Sellman, R.L. and Barr, D.B. (2009) 'Can adolescents learn to create ethical relationships for themselves in the future by reflecting on ethical violations faced by others in the past?' In Martens, M., Hartmann, U., Sauer, M. and Hasselhorn, M. (eds) Interpersonal Understanding in Historical Context. Rotterdam: Sense Publishers, 81-96.

Smith, S.G. (2009) 'Historical meaningfulness in shared action'. History and Theory, 48 (1), 1-19. Online. https://doi.org/10.1111/j.1468-2303.2009.00482.x

Straub, J. (2006) 'Telling stories, making history: Toward a narrative psychology of the historical construction of meaning'. In Straub, J. (ed.) Narration, Identity and Historical Consciousness. New York: Berghahn Books, 44-98.

Swedish National Agency for Education (2018) Läroplan för grundskolan, förskoleklassen och fritidshemmet 2011 (reviderad 2018). Stockholm: Skolverket.

Wilschut, A. (2012) Images of Time: The role of a historical consciousness of time in learning history. Charlotte, NC: Information Age. 